\title{
Learning from 'Good' Practice: What Could African [Universities] Possibly Learn from the Bologna Process and European Students' Mobility? ${ }^{1}$
}

\author{
Okeke, $\mathrm{ClO}$ [PhD]
}

\author{
Doi:10.5901/mjss.2014.v5n23p2092
}

\begin{abstract}
In June 1999, European Ministers of Education and representatives of higher education gathered in Bologna, Italy, and agreed to work towards achieving the European Higher Education Area through a package of structural reforms. This move heralded the Bologna Process (BP). Although the BP has been criticized variously across Europe and elsewhere, however, it appears to be the most profound change encountered by European Higher Education in the 21st Century. The Bologna Process has inspired a number of moves towards restructuring of higher education globally, notably in the United States, Canada, Latin America, Southeast Asia, the Caribbean, and the Arab countries. In this paper, the author assesses developments within Africa's higher education in order to establish in what ways African Higher Education reform initiatives have responded to various global challenges posed by the emergence of the BP. The paper specifically addresses four key questions: i) Has Africa achieved the African Higher Education Area, AHEA? ii) What transparency tools are available within AHEA to enable the interpretation and conversion of academic work from one African country to academic work in another? iii) What mobility frameworks relative to the terms of the $B P$, are there for the African students? And finally, how does African Union (AU) governments' commitment to higher education reforms differ from those of the European Union governments? The author emphasises that learning from good practice is a step in the right direction, and therefore concludes that Africa could still maintain her Africanness while adopting the good practices of other regions such as that offered through the Bologna Process. Doing so, would enable Africa to forge a compatible approach towards the positioning of Africa's higher education to compete with other education systems at the global arena.
\end{abstract}

Keyword: Bologna Process; Transparency tools; Students' mobility; Good practice; African Higher Education Reforms

\section{Introduction: Emergence of the Bologna Process (BP) $1998-2009$}

In June 1999, European Ministers of Education and representatives of higher education gathered in Bologna, Italy, and agreed to work towards achieving the European Higher Education Area through a package of structural reforms (Bishop, 2006; Lunt, 2005; Zgaga, 2003). This move heralded what is now popularly called the Bologna Process (BP). Although the BP has been criticized variously across Europe and elsewhere, however, it appears to be the most profound change encountered by European Higher Education in the 21st Century and portends enormous implications for the rest of the globe (Yavaprabhas, 2009; Yavaprabhas \& Nopraenue, 2008). It equally "set in motion the most significant European cooperation process ever to take place in the field of higher education" (EACEA, 2012, p. 15). Despite both internal and external criticisms (Visser, 2007; Yavaprabhas, 2009) Europe appeared determined, and has forged progressively ahead from Sorbonne in 1998 to Leuven in 2009 to work to position European higher education to be responsive to the needs of an ever-changing continent. Notably, what Europe hopes to achieve through the BP is "a single European Higher Education Area (EHEA) which enables increasing mobility of students and graduates by way of reaching more compatible degrees" (Visser, 2007, p. 4).

That the Bologna is succeeding is no longer in doubt. It is obvious that the global attention, which the BP has received in the past years, is a success grade. The Bologna Process has among other things instigated reactions from across very many regions of the world, for example, in the United States, Canada, Africa, and Southeast Asia (AUCC, 2008; AU, 2007; Adam, 2009; Labi, 2009). Whereas the BP has truly instigated genuine initiatives in some non-EU countries as the US, Australia, and Canada, however, with the exception of South Africa, Mauritius and Tanzania (Balzer \& Martens, 2004; CoA, 2008; Okeke, 2011) it remains very doubtful how Africa as a continent is responding to the ostensible challenges posed by the emergence of the BP. Instead African scholars (Teferra, 2005; Yavaprabhas, 2008; Khelfaoui, 2009; Obasi \& Olutayo, 2009; Okeke, 2010f) have busied themselves critiquing what the BP has and has not achieved for Europe. Nonetheless, an argument, which this writer has sustained in numerous previous publications (see [author name], 2009b, 2009d; 2010c, 2010f; 2011) notes that in the context of the inherited Western-type education,

\footnotetext{
${ }^{1}$ An earlier PowerPoint version of this paper was presented at the IEASA conference held 28th August - 1st September, 2012.
} 
African higher education institutions and governments cannot afford to be inattentive to developments within European education. Doing so, would inevitably result to both academic and other developmental marginalization of Africa as a whole.

It is important to note that the BP does not offer to any country, region or continent any prescriptive one-jacket-fitsall approach. Instead developments within the confines of the BP are Europe's own internal reactions to global changes brought about by the advent of Globalization. This Euro-reaction through educational adjustments to global changes has had obvious impacts on educational developments globally too. In spite of obvious internal challenges facing the Bologna Process (Barros \& Garcia, 2007; Dunkel, 2009; Luichies, 2010; Witte, 2012), yet, the BP appears to offer to the rest of the globe an imperative synergy necessary for intra-continental educational development for economic advancement. In table 1 below, we see the progress that has been made since 1998 through some progressive and concerted efforts by European Ministers of Education and the European Commission.

Table 1: Showing progressively well-concerted efforts by Europe towards achieving the Bologna Process-European higher education area [EHEA]

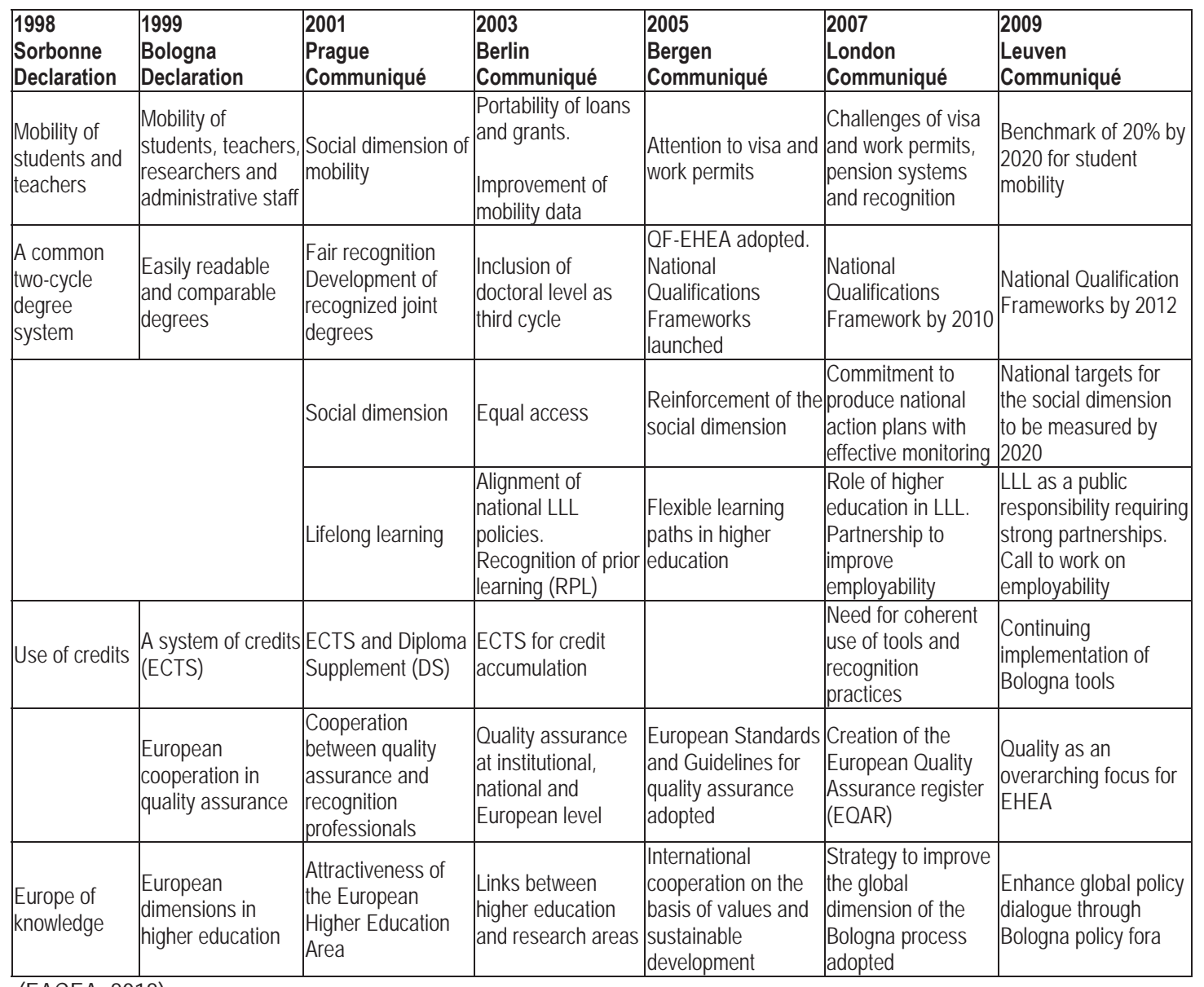

(EACEA, 2012)

One striking quality of the Bologna Process; perhaps a quality that has ensured its relative success is the intergovernmental approach it adopted. For instance, although the BP was initiated by the European Ministers of Education, the BP operational mechanisms are interwoven with the EU policies and processes (Witte, 2012). In the next section of this paper, we shall observe what the BP has achieved for Europe.

\section{What the Bologna Process has Achieved for European Higher Education?}

It must be noted that those with the discernment to twig only through what is bad, will see absolutely nothing when what 
to see is only good. Certainly, we must agree that the emergence of the Bologna process has changed the face of European higher education in an unprecedented manner. One way to measure the impact of the BP is in the context of the global reawakening, which it has generated. The BP dynamism has enlivened the imperativeness of national, regional and continental dialogues in many countries. It has equally succeeded in forcing countries like USA, Canada as well as Australia with little or no history of learning from the outside to begin to pay attention to developments within European higher education (AUCC, 2008; CoA, 2008). Particularly, the Canadian education authorities acknowledges that considering the force with which the BP is impacting globally, it becomes appropriate at this time to respond to this emerging European initiative by at once seizing its related opportunities and facing its challenges (AUCC, 2009; 2009). At present the BP, which took off through the initiative "in 1998 by the four signatories of the Sorbonne declaration: France, Italy, Germany and the United Kingdom" (Khelfaoui, 2009, p. 21), today has 47 European member states all working towards the unification of European higher education. Most importantly too, it must be sincerely acknowledged as EACEA $(2012$, p. 7) has done that "the scale of a project that, on the basis of voluntary cooperation, agrees and implements common objectives for the higher education systems of 47 countries is unprecedented". Europe deserves to be applauded for the developments the Bologna Process has brought into the European higher education, some of which include the following.

Enhanced access into higher education:

Going back to table 1 above it would be observed that the Prague Communique of 2001 recognised the importance of the social dimension of education. Social dimension of the BP acknowledges the diversity that is within the European population that may impact access to higher education. It intends to extricate all obstacles against equitable access to higher education but also those against successful completion amongst both male and female student populations (Balzer \& Martens, 2004; Dunkel, 2009; EACEA, 2012). Enhanced access to higher education involves issues of admission criteria, establishment of alternative pathways to higher education and the recognition of learning outside the formal learning. According to EACEA (2012, p. 9), "in terms of access into higher education, enrolments in higher education increased between 1999 and 2009, although this development was not uniform". In addition, there were also "other measures devoted to widening participation and providing support include the provision of short cycle degrees, active support for students in high schools to enable them to make informed choices about entering higher education, and support for students in higher education" (European Union, 2008, p. 163). Observations were also made that during the said period the emergence of the BP has resulted in tremendous increases in enrolment by gender. For instance, during the period 1999 and 2009, more women enrolled into higher education in Europe (TOBHE, 2009; EACEA, 2012). Although challenges in terms of access still persist, however, the increase in enrolment patterns for both genders indicates an enhanced access to higher education within the Bologna Process boundaries. If current initiatives in Africa towards the African higher education area, are not leading to enhanced access for African students, then the above lesson is something Africa has to emulate.

Establishment of instruments to facilitate study progression:

One of the objectives of the Bologna process is the establishment of a credible mechanism for transparency within the emerging unified European higher education system to enable the achieving of convergence (Barros \& Garcia, 2007; Adam, 2009; Dunkel, 2009; EACEA, 2012). We can observe from table 1 above that right from the Sorbonne Declaration of 1998 to Prague Communiqué of 2001, the establishment of a trust building tool in the form of credit system was paramount. Consequently, the Bologna process has established three very important and currently working mechanisms of trust namely: a three-cycle system [Bachelor, Masters and Doctoral], the European Credit Transfer System, and the Tuning approach. A credit system "reflects the total workload required to achieve the objectives of a programme, which are specified in terms of the learning outcomes and competencies to be acquired" (Woldetensae, 2011, p. 7). The idea of the credit system is to facilitate comparability, which in turn would enhance mobility across borders. On the other hand, the Tuning approach according to (Woldetensae, 2011) reflects a process of harmonisation of higher education programmes by defining learning outcomes of the curricula by subject area. It is observed that the Bologna Process has made tremendous achievements in this regard in that currently about $95 \%$ of participatory universities have adopted the three-cycle programme structure, while $90 \%$ of these universities are already using the European Credit Transfer System, ECTS (Luichies, 2010). This unification of the programme structure within European universities appears to be one of the major achievements of the BP because according to the EACEA (2012, p. 10) the "implementation of the ECTS as a transfer and accumulation system is almost completed" within universities in signatory countries.

Progressively enhancing students' mobility:

Available data shows that the emergence of the BP structure has laid a very solid foundation for a progressively enhanced students' mobility across the Bologna countries. For instance, the EACEA (2012) notes that although this target has not been reached, however, countries within the Bologna agreement have succeeded in bringing about some 
levels of methodological improvements to enable students' mobility especially in the area of credit transfer. It must be noted that countries within the BP agreement are currently undertaking various measures to improve students' mobility within the EHEA. These measures include:

i. The establishment of European level programmes aimed at unifying existing degrees and creating new ones in order to facilitate euro-students' mobility across the EHEA. Such programmes include the Erasmus, the Tempus, the Central European Exchange Programme for University Studies (CEEPUS) and the Baltic Programme NordPlus (Adam, 2009; Dunkel, 2009; EACEA, 2012).

ii. There are also mobility enhancement strategies and programmes, which are developed by various European countries at the national levels targeting students from specific geographic regions of the world. This information is particularly important for skeptics (Obasi \& Olutayo, 2009; Hoosen, Butcher \& Njenga, 2009; Khelfaoui, 2009; Okeke, 2010c) who have suggested that the Bologna Process is designed to cause further brain-drain within lesser developed countries.

There are obvious challenges to students' mobility that are currently being addressed by the BP member countries. Some literatures (Barros \& Garcia, 2007; Adam, 2009; Okeke, 2010f; EACEA, 2012; Witte, 2012) mention some of these challenges to include the following:

i. $\quad$ Lack of funding

ii. $\quad$ Lack of support for international students

iii. Lack of emotional support particularly among those students having to separate from their families over a long period of time

iv. Lack of information

V. Dissonances between foreign students' and host country's national curriculum

vi. Language barriers

Despite these challenges, some progress is still being reported as shown above, and generally Bologna activities have presented to Africa the urgency for actions at continental level if Africa is to positively remain relevant in global matters. EACEA (2012, p. 165) suggests that "national level strategy can serve as an impetus and support to institutional strategies". As nations compete for students' generated revenues, it is important for countries wishing to buy into the Bologna strategies to emulate such approach. This is because the competitive nature of higher education revenues warrants that countries must develop initiatives and strategies to attract the global students' population.

\section{African Responses to the Bologna Initiatives}

The Association of African Universities (AAU) in 2007 initiated a proposal for the launching of what it referred to as the African Higher Education Area (AHEA) (African Union 2008a; Yavaprabhas 2009). This supposedly continent-wide initiative to oversee the affairs of Africa's higher education institutions in terms of policies and practices was in response to various changes taking place at the global arena. One of these changes was the emergence of the Bologna Process (BP). There is also the need for Africa to respond collectively to the challenges, which various elements of globalisation such as the General Agreement of Trade in Service (GATS) commitments in higher education pose to Africa's HEls. Of course as noted by the Ministers of Education of the African Union "globalisation and a competitive world economic order characterised by rapid knowledge generation and technological innovation constitutes for Africa, in equal measure of threat of marginalization as well as opportunities for benefiting and catching up" (African Union, 2008b: 6). It is common practice for scholars to heap blames for Africa's developmental woes to the experiences of Imperialism. Although it may amount to great injustice neglecting such experiences within Africa's higher education discourse, however, many years after most African nations separated from colonial rules it becomes continuously difficult to cling-on to such discourse. Perhaps, time has emerged for African scholars and leaders to get more serious towards finding solutions to the very many challenges facing African education today.

In addressing Africa's response to the Bologna initiatives four clear questions emerged in this paper. However, it is important to note that the questions do not function as parameters for judging Africa's approaches to continental matters. Issues raised in the questions serve to critically direct analysis and discussions in this paper. The questions include the following: i) Is Africa achieving the African Higher Education Area, AHEA? ii) What transparency tools are available within AHEA to enable the interpretation and conversion of academic work from one African country to academic work in another? iii) What mobility frameworks relative to the terms of the BP, are there for the African students? And finally, how does African Union (AU) governments' commitment to higher education reforms differ from those of the European Union governments? Higher education in Africa is faced with huge and complex challenges including:

i. The disparities between tuition fees paid by both the domestic and international African students within African 
universities (Okeke, 2011)

ii. The proliferation of local and foreign higher education institutions in Africa (Okeke, 2010c; 2011)

iii. Gender disparities and mismatch between the acquired and the required skills among graduates (Hoosen, Butcher and Njenga 2009)

iv. Imbalances in terms of the number of students studying sciences and humanities, and rigid admission criteria

v. Lack of modalities for credit transfers between universities and other post-secondary institutions; lack of recognition of prior learning; brain-drain; and the threat posed by HIVIAIDS (African Union, 2007; Yavaprabhas, 2008; Hoosen, Butcher and Njenga 2009)

vi. Funding, disparity in enrolment, infrastructure, governance, graduate employability, capacity-building, equity access and quality assurance (Teferra, 2005)

vii. There is also the need for Africa to respond collectively to the challenges, which various elements of globalization such as the WTO/GATS commitments in higher education pose to Africa's higher education

viii. African governments' continuous lack of sincere commitment towards the development of African higher education.

With these challenges in mind, it is noted that various attempts have been made [while some are still on-going] by the joint committees of Ministers of Education of the African Union, officials from higher education institutions in Africa, as well as other stakeholders including non-governmental organisations within and outside the continent, toward achieving some sort of harmonisation frameworks for African higher education. The earliest of such efforts was in 1981 at Arusha, Tanzania famously referred to as the Arusha Convention, "which was a UNESCO initiative for promoting continental cooperation through the academic mobility of lecturers and students" (Hoosen, Butcher \& Njenga 2009, p. 10). Although this Convention has been revised and improved (AU, 2007; Woldetensae, 2011), one common feature of the agreement, as with the first, was that it has continuously lacked any form of legally binding force to commit the signatories to the agreed framework. For instance, although the Arusha Convention was a legal framework agreement that gave general guidelines, which were aimed to facilitate some continental-level cooperation (AU, 2008a), however, such agreement was never a binding political agenda. As a result, no Member-state was held accountable for failure to implement any section of the Convention as no Member-state was bound to implement. That trend has continued even with the revised and improved version of the Convention.

Numerous other African initiatives have taken place ever since through gatherings such as the Second Meeting of the Committee on Sustainable Development, Addis Ababa, Ethiopia, 26 - 29 November, 2001 (UN 2001); Regional Convention on Recognition of Studies and Degrees of Higher Education in Africa (Shabani 2004); Accra Declaration on GATS and the Internationalisation of higher education in Africa (CHE 2004); Harmonization of Higher Education programme in Africa, which was the main focus of the Conference of Ministers of Education of the African Union (COMEDAF+) held between 29 and 31 May, 2007 at Addis Ababa, Ethiopia (AU 2007); Validation meeting for African Quality Rating Mechanism and Harmonization Strategy for Higher Education held 25th to 27th March, 2008 at Novotel Accra, Ghana (AU 2008a); Conference of Ministers of Education of the African Union (COMEDAF III) 18th to 20th November 2008, Addis Ababa, Ethiopia, where the main agenda was the establishment of the pan-African university (AU 2008b); The AU/NEPAD African Action Plan known as the 10th Africa Partnership Forum (APF), which took place in Tokyo, Japan 7 - 8 April, 2008 (AU/NEPAD 2008); The Dodowa Declaration on African Quality Assurance Network held 15th - 17th April, 2009 at Dodowa, Ghana (AAU 2009); and the Strategic orientations for higher education and research in Africa (UNESCO/WCHE, 2009).

There was also the 1st Pan-African Conference on Curriculum, Literacy and Book sector development, which was the main focus of the Conference of Ministers of Education of the African Union (COMEDAF IV) Steering Committee 24th - 25th September 2009, Addis Ababa, Ethiopia (AU 2009). Although the proposal for the establishment of a Pan African University (PAU) by the COMEDAF III was a step in the right direction, however, the focus of the initiative only on science, technology and engineering appears to weaken the strength of the initiators to truly address Africa's dire need for the revitalization of knowledge. Secondly, the PAU initiative appears bourgeois and elitist, and as such failed even at the proposal stage to demonstrate how it could cater for the needs of the very many remote-dwelling Africans. There have also been some recorded initiatives at the regional and national levels in few countries within the African continent worthy of mention in this paper. Notable examples are the establishment of National Qualifications and Quality Assurance Frameworks in South Africa, Mauritius as well as in Tanzania (Woldetensae, 2011).

The East African Community (EAC) established in 1999 by Kenya, Tanzania, Burundi and Rwanda to oversee the harmonisation of their own higher education systems (TOBHE, 2009). It is noteworthy that one of the achievements of the EAC is the launching of a common higher education curriculum in the medical, technical and agricultural areas for institutions within the EAC. High level of integration progress has also been reported among the French-speaking 
countries on the Maghreb region notably Algeria, Morocco and Tunisia. These countries have clearly adopted a Bologna Process approach to integration by agreeing to realign their national universities programmes in line with the BachelorMasters-Doctoral structure. Put together,

much of the recent collaboration between these nations has been undertaken with a view towards developing a Euro-Mediterranean Higher Education and Research Area. A founding document for the proposed education area, known as Catania Declaration, was signed in January by Euro-Mediterranean countries, as well as Egypt and Jordan (TOBHE, 2009, p. 2)

The West African Monetary and Economic Union (WAMEU) made up of fifteen member nations has also responded to some of the changes brought about by the Bologna Declaration (Yavaprabhas, 2008; African Union, 2009; TOBHE, 2009; Okeke, 2011; Woldetensae, 2011). Recently for instance, the WAMEU member-states adopted a resolution to facilitate academic level mobility among citizens of the WAMEU nations by easing immigration and admissions restrictions for prospective students. There are many more instances of both national and regional levels initiatives that space have not allowed for mention here.

Notwithstanding these initiatives however, there have been some general weaknesses that continuously hunt efforts towards integration in Africa's higher education whether at the national, regional or continental levels, which include but not limited to the following:

i. Lack of visionary leadership within higher education institutions and education departments in Africa

ii. Lack of visionary political institutions of governance on the continent to directly impact social development

iii. Abject dissonances within the visions and missions of various higher education institutions in Africa

iv. Non-commitment to true internationalisation of higher education programmes by many African higher education institutions

v. Highly uncompromising higher education ideologies among African educators and institutions in Africa

vi. Corrupt practices within some education institutions on the continent that result in the production of the wrong caliber of professionals to take charge of affairs of education at ideological levels

vii. Disgraceful social instabilities resulting mostly from hatred and unnecessary wars within the continent

viii. High level economic disparities and poverty, among individuals and nations on the continent

ix. Indifference attitudes to the necessities for change among some prominent scholars and institutions in Africa

$x$. The general lack of genuine and sincere commitment from African heads of governments and the African Union

Thus in responding to the earlier questions raised above, it is obvious that Africa is as yet to establish any credible framework as observed in table 1 towards achieving continentally acceptable higher education area as with the BP. It is still very difficult to measure whether any achievement has been made in the area of transparency tools within the proposed African Higher Education Area (AHEA) to enable cross-country interpretation and conversion of academic work of African university students. It is true that few universities mainly within South Africa have established some prior learning recognition frameworks, but that is just a country-wide initiative, which is not without flaws. There is currently no genuine mobility framework relative to the terms of the BP that exist for African students anywhere on the continent. Although 'internationalisation' is nowadays frequently used by many African universities, yet, it is noted that

whereas across the Atlantic, say in Europe, the phrase international student is used to differentiate between the student from the EU country and others from outside of the EU...the African conception of the phrase appears to be different. A student who is classified an international student within an African university is one who does not hold any of the elements of citizenship as defined by the immigration law of the country where the university is located. Such is not peculiar to any one country or region within Africa but appears to be an unquestioned practice throughout the entire continent (Okeke, 2011, p. 439)

It is not the intention of this author to politicize the aim that he has set to achieve in this paper. However, it appears unavoidable to comment on African Union (AU) governments' lack of genuine commitment to higher education reforms in Africa. Most African countries appear to be currently preoccupied with all manner of evils against its citizens ranging from coups, election and boundary disputes, political killings and other human disappearances, corruption, kidnappings to open battle conflicts and wars. There is a genuine feeling of lack of commitment to better living standards for Africans by their leadership. Such has been a major reason why majority of African leadership do not really border about the welfare of the citizens they have vowed through oat to protect. Most importantly, in comparison to the quality of the European Union Ministers and Secretaries of Education, it is arguable whether some of their African counterparts do really possess the requisite attributes necessary for the task of educational advancement when their experiences are required at the level of deliberations. The above weaknesses have therefore made imperative the fact that Africans must look towards the Bologna Process for some lessons. Perhaps that appears to be what the Ministers of Education of the AU meant 
when they suggested that "it is advisable for African Union to pursue its own African harmonization process, drawing on the lessons learned in Europe" (African Union, 2008a, p. 56). The final part directs attention to these lessons.

\section{Some lessons Africa should learn from the developments within the Bologna Process}

BP portends a progressively unifying and genuine process of continental academic advancement:

The BP operations resonate through finding solutions to variety of acknowledged and well-defined Europeanbased problems. It has to be agreed (as shown in table 1) that in spite of its shortfalls, the processes, which started in Sorbonne in 1998 down to Leuven in 2009 have been genuine, progressive and unifying. Particularly, the Bologna Process has transformed the face of European higher education because a solid foundation is laid for a European higher education, which is designed to serve the ever-changing variety of European societies' needs. It is worthy to note that all the 47 participating nations are committed to the Bologna declaration leading to various modifications in the structures of higher education in European universities (EACEA, 2012). Most importantly, it is the BP, which has led to EU continentwide identification of a number of issues that have informed the social dimension of the European higher education. A further look at the table above will reveal that during the 2009 Leuven communiqué a new target date was established in what was referred to as the Vision 2020. European nations and institutions do not have to wait for a legally-binding agreement (argued as major weakness of the Arusha Declaration) to adopt the principles of the BP. Instead, the relative success that the BP has recorded is made possible by the sincere and genuine sense of commitment by European nations to see to it that European higher education is responsively capacitated towards solving societal needs irrespective of the consequences of this to other continents. That is a good lesson Africa must learn.

Challenges within global higher educations are made common by the flood of Globalisation:

The Bologna Process (BP) represents "an attempt to coordinate responses to major challenges facing European Higher Education through a package of structural reforms" (Lunt, 2005, p. 89). Most of these challenges are brought about by the emergence of globalisation, thus making imperative the need for excellence, cooperation and competition through a well-coordinated European level higher education. According to Teferra $(2005$, p. 4) "most of the problems the European Area grapples with, are also everyday realities in Africa, which necessitates the need to draw valuable and relevant lessons" from the BP. Some critiques (Khelfaoui, 2009; Obasi \& Olutayo, 2009; Teferra, 2005) may argue that Africa's share of these challenges may differ in magnitude with those of Europe. However, what is important (which is worth learning) is the nature and manner with which Europe is responding to the challenges facing European higher education. European nations and institutions have responded jointly through the BP to challenges, which they have unanimously understood as common European problems. If African higher education is to be adequately and responsively positioned towards solving Africa's societal needs the BP is a lesson, which Africa must not turn a blind eye to. That is why Teferra $(2005$, p. 4) argues that "common regional responses to growing common challenges, as in Bologna, remain the obvious alternative for Africa".

'In unity we stand' as a BP lesson worth learning-Ubuntu re-enacted:

As with most African nations, the capacity of some European countries to address the numerous challenges of nation-building is very weak. However, in the spirit of the larger EU Commission the BP offers a united opportunity to some weaker EU member-states to benefit from a well-coordinated and genuine continental academic advancement. Although this opportunity is not without blemishes as Luichies (2010) has rightly noted however, evidence as we have already discussed in this paper shows that the BP has succeeded in bringing about some levels of methodological improvements to enable students' mobility especially in the area of credit transfer (EACEA, 2012). This united approach to problem-solving appears to be informed by the imperativeness of globalisation, which extends most national problems across international boundaries such that the internal problems of a particular nation implicate the internal security of another. This again is a lesson that Africa most learn, more so because most African countries are experiencing profound difficulties in their individual abilities to tackle various challenges particularly posed by the rampaging force of globalisation.

The above point appears plausible argues Teferra (2005) because the ability of most African countries to deal with national problems let alone regional ones, is currently very limited. It becomes necessary therefore for African nationstates to borrow a leaf from Europe's BP formulae; doing so would be in the spirit of Ubuntu, which invigorates that spirit of love and care. Africans must show genuine interest in the affairs of fellow Africans as a starting point, meaning that

everyone must be carried alone; that justice must prevail; that communalism must prevail over individualism without which the spirit of such philosophy [as Africanisation] stands defeated. It upholds the spirit of Ubuntu [in South Africa, a Zulu word and an Eastern Nigeria synonym of Igwebuike, an Igbo word], which implies humanity, unity, and togetherness of Africa's peoples (Okeke, 2011, p. 433). 
African peoples can draw genuinely from the spirit of Ubuntu because it encompasses some basic principles of humanness, caring, sharing, respect, and compassion (Broodryk, 2006; Okeke, 2011), in confronting the very many educational and other social problems besetting academic advancement on the continent. Adopting a sincere and pragmatic continental approach to common African problems as demonstrated by the Europeans (as always) through the $\mathrm{BP}$, would enable Africans to develop constructive strategies to deal with Africa's abilities to confront global matters.

A lesson from BP's transparency tools - the credit transfer system and tuning approach:

Although the BP has been severally criticized by many for what it has and has not achieved (e.g. Adam, 2009; Dunkel, 2009; Khelfaoui, 2009; Labi, 2009; Obasi \& Olutayo, 2009), however, it must be noted that the Bologna Process is Europe's direct reaction for common European answer to common European problems (Teferra, 2005). Part of this reaction is the realization of the need to establish a compatible academic system leading to the adoption of the credit transfer system and the tuning approach. Known as the European Credit Transfer and Accumulation System (ECTS), this is one of the transparency tools established to enable the comparability and compatibility of programmes within European higher education (Woldetensae, 2011). Within the EU, the mechanism was aimed to facilitate the mobility of EU students; it was also adopted as a quality assurance mechanism against which international students from non-EU countries' qualifications are being assessed. The ECTS allows for the description and quantification of programmes and certificates thereby enabling the obstacles associated with the mobility of European students in particular being progressively eased. On the other hand, a tuning approach, "is the process of harmonizing higher education programmes by defining learning outcomes of the curricula by subject area" (Woldetensae, 2011, p. 7). Tuning aims to identify reference points for generic and subject-specific knowledge and skills that allows for agreed learning outcomes to be established. Two major advantages of this approach are, first, it serves as a reference against which various European curricula would be measured, and second, it is meant to facilitate programmes transfer by EU students between institutions.

Although some institutions in South Africa such as the South African Qualification Agency (SAQA) and the Council on Higher Education (CHE) play related roles, while various universities have adopted the recognition of prior learning policies, however, these are nothing but internal quality assurance control mechanisms that are operationalized only in South Africa. Notwithstanding, these attempts do not represent any continental approach to continental educational problems. While various harmonisation and quality assurance attempts are on-going, both the Credit Transfer System and the Tuning Approach could provide for Africa, a unified continental approach to common continental problem. Adopting both tools could offer important potential towards facilitating African students' mobility and for the harmonisation of higher education programmes in Africa. It is imperative for a common mechanism to be developed at a continental level that would allow for common comparism of programmes and qualifications across institutions in Africa.

The European Commission approach to the Bologna Process as exemplary lesson:

In addressing the question on how the African Union (AU) governments' commitment to higher education reforms may differ from those of the European Union, an institutionalist approach becomes imperative (Rhodes, 1997; Reinalda \& Verbeek, 1998; Balzer \& Martens, 2004). Balzer and Martens (2004, p. 7) discern three forms of governance namely "governance by coordination from exclusion to inclusion; by opinion formation from redefining the Commission to adding new targets; and by instruments through financial capacities" that have enabled the European Commission to effectively participate in the BP initiatives. While space does not allow for a detailed analysis of these forms of EU-BP collaboration, Balzer \& Martens (2004) note that there are two lessons, which the approach offers to other regions hoping to draw credence from the BP. The authors noted that governance by coordination and opinion formation appear to be highly and surprisingly influential especially when by virtue of its authority the EU could have invoked some legal instrument (something proponents of the Arusha had wished to see) to enforce the BP principles on member-nations. It is therefore argued in this paper that it was wrong to suggest that the Arusha Declaration has failed to achieve its objectives because the agreement was not a legally-binding document.

A second lesson that the AU member-states must learn from the EU-BP partnership is EU's ability to successfully incorporate the BP initiatives into its institutional structures in spite of the fact that the Commission was excluded from the original agenda (Barros \& Garcia, 2007; Reinalda \& Verbeek, 1998; Adam, 2009). It must be noted that earlier before the Prague Communiqué of 2001, which formally invited the EU to the Bologna Process, the Commission was completely excluded by the initiators of the Process. Currently, the EU serves as vehicle on which the BP operations revolve. Moreover, the EU has also successfully incorporated the affairs of the BP as integral to its programme of activities (Balzer \& Martens, 2004). The African Union (AU) must undertake a study of the EU approaches to the BP in order to understand how its supportive governance and educational policies have enabled the BP to progressively achieve its objectives. In addition to that the AU must have the right caliber of personnel; those with the attributes to move African education forward, within its ranks if it intends to achieve this great task. However, within an inherent legacy in which some members of the AU leadership and their cohorts emerge through incredulous processes, it becomes worrisome whether 
the AU ranks is capable of producing the right caliber of personnel to enable it perform such role as with the EU.

\section{Concluding Remarks}

The objective of this paper was to explore some of the BP lessons that could inform continental-level education policy initiatives and developments capable of responding to the needs of the African societies. The Bologna Process was adopted for this analysis not because the author thought that the BP is flawless; far from it. The rationale for mirroring the $\mathrm{BP}$ in this paper is because it represents Europe's most profound attempt at providing purely European solutions to problems besetting Europe's higher education. A second reason for adopting the BP in the analysis presented in this paper is because of the fundamental impact the BP has had not only on Europe's higher education systems, but also on the higher education systems across its continental borders. The BP has had far-reaching implications for the education systems in Australia, Canada, the United States, and Southeast Asia that Africa can no longer afford to turn a blind eye or comfort itself with intellectual critiquing. Discoursing on what the BP has or has not achieved should no longer be the priority of African scholars; for the BP has among other things changed the face of the European higher education leading gradually to the much-desired European Higher Education Area (EHEA). Most importantly, arguing whether the BP represents a new form of Imperialism does not change the reality, which such Euro-initiative offers to Europe in particular.

Historically, Europe has always moved to proffer solutions to Europe's internal problems even when it involves finding such solution from other continents as with the trans-Atlantic slave trade that was necessitated by the need for slave labour, and as with Imperialism made possible by the contradictions within the Capitalist mode of production. Casting blames on Europe for finding solutions to its internal problems (as we can see through the emergence of the BP) does not represent any sensible approach to finding solutions to Africa's numerous problems; some of which were created by Africans themselves. Africa's fore-fathers and fore-mothers may be excused for their roles in facilitating the so-called Europe's underdevelopment of Africa many centuries past. However, with the $21^{\text {st }}$ century advancement cutting across every continent, and with countless numbers of higher education institutions across Africa, it would be an inexcusable error if Africans fail to provide solutions to the numerous problems crippling the African societies. Africans must develop the habit of learning from good practices, part of which has been offered by the emergence of the Bologna Process. The challenges besetting African higher education systems are profound. Finding solutions to such challenges aren't going to be very easy either. However, a fundamental requirement for progress in this regard is for Africans to begin to cultivate the spirit of sincerity of purpose that allows the human mind to be susceptible only to achieving good. African higher education scholars, other higher education stakeholders and the AU leadership should emulate the good spirit and integrity to achieve that reverberates among the BP initiators, which enables the BP to be succeeding in spite of some obvious difficulties confronting it.

\section{References}

AAU (2009). The Dodowa Declaration on African Quality Assurance Network held 15th - 17th April, 2009 at Dodowa, Ghana. Retrieved 10 November 2009 from: http://www.aau.org/qa/dodowa09/

Adam, S. (2009). Regional higher education cooperation in the next decade: the Bologna process and Europe-Asia dialogue: Summary of proceedings. Brussels: EU-Asia Higher education platform.

African Union (2008a). Provisional agenda and programme of work. Validation Meeting for African Quality Rating Mechanism and Harmonization Strategy for Higher Education held 25th to 27th March, 2008 at Novotel Accra, Ghana. Retrieved 10 November 2009 from: http://www.africa-union.org

African Union (2008b). Establishing PAN-African universities in the Second Decade of Education for Africa. Second Session of the Bureau of the Conference of Ministers of Education of the African Union (COMEDAF III) 18th to 20th November 2008, Addis Ababa, Ethiopia. Retrieved 10 November 2009 from: http://www.educationdev.net/edudev/docs/ConceptPaper2_Aug.PDF

African Union (2009). Report of the 1st Pan-African Conference on curriculum, literacy and book sector development: Rebuilding education in Africa. Conference of Ministers of Education of the African Union (COMEDAF IV) Steering Committee 24th - 25th September 2009, Addis Ababa, Ethiopia. Retrieved 10 November 2009 from: http://www.africa-union.org/root/ar/index/

African Union, AU (2007). Harmonisation of higher education programmes in Africa: Opportunities and challenges. $3^{\text {rd }}$ ordinary session of the Conference of Ministers of Education of the African Union (COMEDAF III), 6 - 10 August, 2007, Johannesburg, South Africa. Retrieved from: http://www.africa-union.org/

Association of Universities and Colleges of Canada, AUCC (2008). Canadian universities and the Bologna process. Canada: AUCC.

Association of universities and Colleges of Canada, AUCC (2009). The Bologna process and implications for Canada's universities. Canada: AUCC.

AU/NEPAD (2008). The AU/NEPAD African Action Plan. 10th Africa Partnership Forum (APF), Tokyo, Japan 7 - 8 April, 2008. Retrieved 22 October 2009 from: http://www.africanpartnershipforum.org/dataoecd/ 
Balzer, C., \& Martens, K. (2004). International higher education and the Bologna process: What part does the European Commission play? Paper presented to the epsNet 2004 Plenary Conference, 18 - 19 June 2004, Charles University, Prague. Retrieved from: http://www.staatlichkeit.uni-bremen.de

Barros, J. P., \& Garcia, L. (2007). The Bologna Process as a motivator for change. Proceedings of the Informatics Education Europe II Conference, IEEll: 146 - 153.

Broodryk, J. (2006). Ubuntu: Life coping skills from Africa. Johannesburg: Knowres.

Commonwealth of Australia, COA (2008). Recognition of higher education qualifications across the Brisbane Communiqué region. Scoping study and report commissioned by the Department of Education, Employment and Workplace Relations. Australia: Department of Education, Employment and Workplace relations.

Council on Higher Education, CHE (2004). Accra Declaration on GATS and the Internationalisation of higher education in Africa. Retrieved 19 July 2009 from: http://www.che.ac.za/documents.d000060/AccraDeclaration-final.pdf

Dunkel, T. (2009). The Bologna Process: Between structural convergence and institutional diversity. European Journal of Vocational Training, 46(1): 174 - 195.

Education, Audiovisual and Cultural Executive Agency, EACEA (2012). The European higher education area in 2012: Bologna process implementation report. Retrieved from: http://eacea.ec.europa.eu/education/eurydice

European Union (2008). The first decade of working on the European higher education area: The Bologna Process independent assessment. Brussels: The European Commission.

Hoosen, S., Butcher, N., \& Njenga, B. K. (2009). Harmonisation of higher education programme: A strategy for the African Union. African Integration review, 3(1): 1 - 35.

Khelfaoui, H. (2009). The Bologna Process in Africa: Globalization or return to colonial situation? Journal of Higher Education in Africa, $7(1 \& 2): 21-38$.

Labi, A. (2009). Europe's higher-education restructuring holds lessons for U.S., Report says. The Chronicle of Higher Education. Retrieved from:

Luichies, M. (2010). Clean your house before you invite guests: How to make the Bologna survive the financial crisis. The Netherlands: University of Humanistics, Utrecht.

Morse, J. A. (2009). Lessons learned from the Bologna Process. ACE Annual Meeting, February, 2009. Retrieved from:

Obasi, I. N., \& Olutayo, A. O. (2009). Globalization, the Bologna process and African universities: Limits and contradictions of the market-oriented higher education reforms. Journal of Higher education in Africa, 7(1\&2): 159 - 187.

Okeke, C. I. O. (2009b). Issues pertaining to the theoretical framework of a study: Reflections from some universities in three African countries. The Nigerian Journal of Guidance \& Counseling, 14(1): 58 - 70.

Okeke, C. I. O. (2009d). A neglected impediment to true Africanisation of African higher education curricula: Same agenda, differential fee regimes. Paper presented at the 3rd IAACS World Curriculum Studies Conference held between 07 - 10 September, 2009 at The NH Lord Charles Hotel, Somerset-West, Cape Town, South Africa.

Okeke, C. I. O. (2010c). Africanisation and Cultural globalization: A convergence or subservience of culture? In N. T. Ekeanyanwu \& C. I. O. Okeke. Indigenous societies and cultural Globalization in the 21st Century: Is the global village truly real? Germany: VDM Publishing House. ISBN-13: 978-363925760-1

Okeke, C. I. O. (2010f) African Higher Education Area (AHEA): Might this bring about the African fee status for the African citizens? Paper presented at the 14th IEASA Annual Conference held between 28 - 31 August, 2010 at the University of the Witwatersrand, Johannesburg, South Africa.

Okeke, C. I. O. (2011). Domestic and international tuition fees in African universities: Might this impede the quest for Africanisation of higher education? SAGE: Journal of Studies in International Education, 15(5), 429 - 444.

Reinalda, R. \& Verbeek, B. (1998). Autonomous policy making by international organisations: Purpose, outline and results. In R. Reinalda \& B. Verbeek (Eds). Autonomous policy making by international organisations. London: Routledge.

Rhodes, R. A. W. (1997). Understanding governance. Buckingham: Open University Press.

Scott, J K. (2009). The Bologna process: Action steps for US universities. Missouri: University of Missouri International center.

Scott, L. K. (2012). Bologna and beyond: The future of higher education in the United States. Synesis: A Journal of Science, Technology, Ethics, and Policy, p. $1-3$.

Shabani, J. (2004). Regional Convention on Recognition of Studies and Degrees of Higher Education in Africa. Retrieved 22 July 2009 from: http://dev.aau.org/wto-gats/papers/shabani.pdf

Teferra, D. (2005). The Bologna Process: the experiences - and challenges - for Africa. A paper presented at the Third Conference on Knowledge and politics, The University of Bergen, 18 - 20 May, 2005. Retrieved from:

The Observatory on Borderless Higher Education, TOBHE (2009). In Europe's footstep? Towards regional co-ordination of higher education in Africa and South-East Asia. Retrieved from:

Toma, S. G., Ardeleanu, M., \& lanole, R. (2009). Quality assurance and employability: lessons from the University of Bucharest. Bucharest: QA department, University of Bucharest.

UNESCO/WCHE (2009). Strategic orientation for higher education and research in Africa. Retrieved 22 July 2009 from: http://www.unesco.org/education/WCHE2009/

United Nations (2001). Sustainable development policy in Africa: Harmonizing population and economic growth in the process of implementing the ICPD programme of action. Second meeting of the Committee on Sustainable Development, Addis Ababa, Ethiopia, 26 - 29 November, 2001. Retrieved 4 March 2010 from: http://www.uneca.org/csd/population.pdf 
Visser, T. H. (2007). The Bologna Declaration and its implementation in Russian higher education: Case study Kazan State University. Doctoral thesis. Russia: Kazan State University.

Witte, J. (2012). Is there an ideal road to Bologna? Paper presented at the International Workshop 22 May, 2012, Mishkenot Sha'aninim, Jerusalem.

Woldetensae, Y. (2011). Reinforcing the African Union harmonisation strategy towards establishing the space of higher education in Africa: Some pragmatic approaches. Paper presented at the Conference of Rectors, Vice Chancellors and Presidents of African universities (COREVIP), Stellenbosch, South Africa, May 30 - June 3, 2011.

Yavaprabhas, S. (2008). SEAMEO RIHED and the progress towards a common space of higher education in Southeast Asia. Bangkok: SEAMEO RIHED.

Zgaga, P. (2010). The Bologna process: Actions taken and lessons learnt. Austria: Bologna Policy Forum. 